\title{
Evaluation of Inclusion Thematic Class in Special Needs Students at SD Barusari 01 Semarang
}

\author{
Bilal lutfi Mas'ut1*, Purwadi², Mudzanatun³
}

1,2 Jurusan Pendidikan Guru Sekolah Dasar, Fakultas Ilmu Pendidikan, Universitas PGRI Semarang

A R T I C L E I N F O

Article history:

Received 15 February

2019

Received in revised

form

29 March 2019

Accepted 18 April 2019

Available online 25 May 2019

Keywords:

evaluation, thematic learning, inclusive class, students with special needs.

\section{A B S T R A C T}

The purpose of this study was to find out how the implementation of inclusive class thematic learning, especially in terms of planning, implementation, and evaluation of learning outcomes in students with special needs SD Barusari 01 Semarang. The research method used is a qualitative descriptive method. Based on the results of data analysis and discussion it can be concluded that in terms of planning of learning carried out by the teacher includes planning in the form of syllabus, rpp, preparation of learning media and approaches taken by the teacher which later makes ABK students feel comfortable in attending the lesson well planned. The results of the analysis plan for the implementation of thematic learning with a percentage of $99 \%$. For the implementation of learning it is also well implemented, can be seen from teaching and learning activities between teachers and students both in theory and practice mutually supportive. The results of the analysis of the implementation of thematic learning reached a percentage of $85 \%$. For evaluation of learning to run well also seen from the results of the assessment of learning outcomes which reached a percentage of $75 \%$. 


\section{Introduction}

Education is a conscious and planned effort to create an atmosphere of learning and learning process so that students actively develop their potential to have religious spiritual strength, self-control, personality, intelligence, noble morals, and the skills needed by themselves and the community (Law on Social and Political Sciences No.20 in 2003).

In the mandate of Undang-undang Nomor 20 Tahun 2003 concerning the National Education System it is emphasized that education in Indonesia is carried out democratically and fairly and is not discriminatory by upholding human rights, religious values, cultural values, and national diversity. Every citizen is guaranteed and has the same right to obtain quality education. This means that there are no exceptions for citizens who have physical, emotional, mental and social disorders. The intended citizens are citizens with special needs who have physical, emotional, mental and social disabilities. Children with special needs are children who in their education need specific services, which are different from children in general. Children can be said to have special needs if there is something lacking or more in the child which shows special characteristics in its recognition.

Children with special needs have the same rights as children in general to obtain education at all levels of education. This type of education for children with special needs is called special education. Special education for students who have disabilities, serves to provide educational services for students who have difficulties in following the learning process because of physical, emotional, mental, and social disorders. The aim of special education is to develop learners' potential optimally according to the types of learning barriers, their needs and abilities. Special education providers can be carried out through special education units, general education units, vocational education units, and / or religious education units (Pasal 130 ayat 2 PP Nomor17 Tahun 2010 tentang Pengelolaan dan penyelenggaraan pendidikan).

Learning evaluation is the process of determining the results achieved by several activities planned to support the achievement of objectives (Arikunto, 2010: 2). Evaluation is very important in a learning process. Evaluation is used to see and know the processes that occur in the learning process. Schools certainly have to do an evaluation in each learning process, so they know what needs to be improved or eliminated in the learning process later.

Improving the quality of learning in schools will always get continuous improvements. Improvement and improvement of learning in schools is done through changes in the school curriculum by the government. The government (Kemdikbud) starting the new school year (2013) will implement a new curriculum at all levels of school education from elementary / MI, junior high / MTs, high school / MA / vocational schools from the 2013-2014 academic year, will implement a new curriculum, especially in schools the SD / MI level will get quite a large portion of the changes. One of the features of the 2013 curriculum is its integrative templates at the level of primary education.

Primary education (Elementary School) currently use integrated thematic learning in childcentered. Thematic learning is integrated learning that uses themes to link several subjects so as to provide meaningful experiences to students. The theme is the main thoughts or ideas that are the subject of discussion (Poerwadarminta, 1993). The determination of the thematic approach in learning in the low class by the National Education Standards Agency (BSNP) is inseparable from the development of the concept of the integrated approach itself.

According to Abdul Majid (2017: 85) Thematic learning has concepts that can be said as teaching and learning approaches can involve fields of study to provide a variety of meaningful experiences to children because children will understand the concepts they learn through direct experience and connect them with other concepts they already understand. Meaningful means that in learning students will be able to understand the concepts they learn through direct and real experience that links between concepts in intra and between subjects.

The Implementation of thematic learning, several things need to be done which includes the planning stage which includes mapping basic competency activities, developing a theme network, developing a syllabus and preparing a learning implementation plan. The implementation phase of thematic learning is the implementation of teaching and learning process activities as a core element of learning activities which are implemented in accordance with the guidelines that have been prepared in the previous planning. Procedurally, the steps taken are implemented into three steps, namely the initial or opening activities, the core activities and the final activities (closing). Abdul Majid (2017: 96).

One of the elementary schools that organizes inclusive education is SD Barusari 01 Semarang Seeing the number of children with special needs (ABK) who are entitled to get a good standard of education, they provide opportunities for people with disabilities or children with special needs to study at their schools, as long as their IQ is able to participate in academic activities. And they also have the right to play with other normal children so that the creation of harmony for children with special needs with 
other normal children, see the potential of SD Barusari 01 Semarang which is strategically located in the city center and many teachers are able to carry out mandate to teach children with special needs in terms of learning, although many teachers have changed, but teachers who enter SD Barusari 01 Semarang can still be good teachers for children with special needs.

SD Barusari 01 Semarang is not a pure inclusion school and there is no government decree yet, but because the Department of Education entrusts a number of children with special needs at SD Barusari 01, so this school is called an incusion school, therefore the form of administration consists of rpp, syllabus, same as public schools.

Based on observations made by researchers at SD Barusari 01 Semarang, especially in Grade 4, there are 4 special needs students with different characteristics, namely autism and slow learning which requires special attention from the teacher in the learning process. The four children are included in the inclusion or special needs, the child has experienced the disorder since grade 1 elementary school Barusari 01 Semarang and continues until grade 4 as it is now, then there are still many other causes such as slow learning, the average child in Grade 4 is slow in learning even students who are not classified as having special needs according to grade 4 teachers are also slow in learning but not too severe.

The cause of the disorder arises from various causes, but the children continue to be enthusiastic in following the learning delivered by the teacher despite their shortcomings, for their own parents leave their children in SD Barusari 01 but because most of them are spoiled by their parents when being at home so that it gets to school children with special needs are spoiled, it can be seen when they are still in a low class whose mother always waits until school which makes the child unable to be independent, it makes the teacher a challenge because must provide approaches to children with special needs.

According to the observations of researchers, the school has several students with special needs in each class, among others: students of dysgraphia ie students who have difficulty in writing, dyslexia ie students who are able to understand reading content is very low, dyscalculia ie students who have difficulty learning to count (mathematics), and students whose learning achievement is very low. These students really need special attention from the teacher in the learning process activities compared to other students.

Inclusion schools are not schools in which children with special needs, there are filled by children with special needs and normal children in general, but in SD Barusari 01 Semarang in every class, especially grade 4 children with special needs are able to join and mingle with other normal children, even when learning normal children always help children with special needs when they have difficulty in learning, it is applied by the teacher in establishing harmony between children with special needs with normal children, normal children are always given a briefing to always love children who have it is not mocking or bullying, there have never been cases of bullying, especially in grade 4 SD Barusari 01 Semarang because of the attitude of his friends who always love and support children with special needs in every learning.

The planning process at SD Barusari 01, the teacher determines the theme in accordance with the teacher's manual or often called the teacher's book and is adjusted to the themes and sub-themes that will be taught to students, and then the teacher prepares a Learning Implementation Plan (RPP). After preparing the lesson plans the teacher prepares learning media according to the learning implementation plan that has been made, but not every subject the teacher always prepares learning media.

At the implementation stage of thematic learning in SD Barusari 01 class 04 implementation of learning is still lacking in personal preparation, normal students and special needs still use the same themes and sub themes, for students with special needs in the class the application of models, methods and media learning cannot be absorbed by students with special needs when the learning process is taking place, such as when teachers apply the group method, students with special needs are still difficult to join with other normal children in the learning process. Not infrequently they are cool to play alone and it is difficult to be invited to focus on the lesson, although the teacher always asks normal children to help students with special needs when difficult, but it does not affect ABK students because of their difficulty in receiving subject matter. Thematic learning should create an active but seemingly passive learning environment, even though the handling of the teacher given is special attention, ways for children with special needs to be accepted, and ways for inclusive children to be more confident. Thematic learning cannot be fully accepted by students with special needs.

At the evaluation stage, the minimum completeness criteria (KKM) always puts students with special needs low or does not match the results achieved, it happens because here the material given by the teacher cannot be received by students with special needs to the maximum, evaluation and special attention have been made by the teacher before the evaluation of the final stages of learning for students with special needs, but from the small evaluation students have not been able to complete the questions the teacher gave even though they have been assisted by normal friends. 
Based on these descriptions, the authors intend to conduct research on "Evaluation of Thematic Learning Inclusion Classes on Students with Special Needs at SD Barusari 01 Semarang Subtema 1 Kelas 4 Semester 2"..

\section{Methods}

Subjects in Waka Curriculum research and Class IV Teachers of SD Negeri Barusari 01 Semarang. Research objects related to the evaluation of inclusive class learning in students with special needs include; (1) thematic learning planning for inclusive classes; (2) the implementation of the inclusion class dramatic learning; and (3) evaluation of thematic learning outcomes of inclusive classes.

This type of research is qualitative research. This type of research is qualitative research. Qualitative research is research based on reality / symptoms / phenomena that occur in the field. Data analysis is based on facts found in the field and then constructed into a theory (Sugiyono, 2010: 8). Data analysis in this research was conducted descriptively, so the data analysis used was a descriptive qualitative technique. The evaluation model used is an stakeholder evaluation model that distinguishes three phases in evaluation, namely preparation, process and output.

The initial step in this research is a preliminary study. In this preliminary study there were several steps carried out, including literature study and field survey. The second step is the preparation phase. In this preparation stage, observations were made to collect data on the thematic learning of inclusive classes in students with special needs in fourth grade at SD Negeri Barusari 01 Semarang. The next step is the implementation phase. At this implementation stage the researchers conducted interviews with vice principals in the field of curriculum, fourth grade teachers, and questionnaires in the form of planning, implementation and evaluation. The final step is exposure. Each of the results of the research analysis is concluded and then presented in the form of a discussion of research results.

\section{Result And Discussion}

According to the Directorate of SLB Development (2007), inclusive education is an education service system that provides opportunities for all children to learn together in public schools by paying attention to diversity and individual needs, so that the child's potential can develop optimally.

Evaluation of learning in this study is intended to conduct an investigation of the learning process that takes place in inclusive classes, especially for students with special needs in class IV SD Negeri Barusari 01 Semarang.

At the thematic learning stage begins with the assessment of the Learning Implementation Plan (RPP). The components of the lesson plan include the identity of the subject, the main component of the lesson plan, and the completeness of the lesson plan component. The RPP component consists of KI, KD, and IPK formulations, formulation of learning objectives, learning materials, learning methods, learning media and learning resources, steps of learning activities, and assessment. (Pusat Kurikulum PBM dan PPL, Universitas PGRI Semarang 2019).

At the stages of the implementation of thematic learning includes several aspects, including preliminary activities, core activities (mastery of subject matter, implementation of learning strategies that educate, application of scientific approaches, use of learning resources or media in learning, use of correct and appropriate language in learning), assessment, and closing learning. (Pusat Kurikulum PBM dan PPL, Universitas PGRI Semarang 2019).

Based on the results of research evaluating the thematic learning process of inclusive classes in students with special needs in fourth grade SD Negeri Barusari 01 Semarang, the following data are obtained.

Inclusion classes are designed to develop abilities between normal students and students with special needs, the number of students with special needs in 4 grade is four students. Each has different disadvantages, but is more dominant in slow learning (slow leaner). Students with special needs are made into their own groups in the classroom and accompanied by one normal student. This is done in order to control the students, because students with special needs are different from other normal students. The material that students learn has the same needs as normal students, which distinguishes only in the grading system.

There is no specific method, the teacher uses the approach to special needs students so that they feel comfortable and happy with the teacher. For facilities and infrastructure in the classroom, the teacher uses the LCD Projector and various images to explain the material, because students are more interested in the media, including for ABK. Thematic books also continue to be used for learning activities. 
Learning planning conducted by the teacher includes planning in the form of lesson plans, syllabus, and other administrations already included in the complete category. The teacher is able to prepare all necessary learning preparations. Learning Implementation Plan (RPP) made between normal students and students with the same special needs. The difference is the standard assessment. The teacher also plans materials to be delivered usually by using video media. Even so, students with special needs are still able to continue to follow learning.

The process of implementing learning in class, the teacher approaches first to students with special needs. This is done so that students feel comfortable following the learning, so learning can run with the expectations of the teacher. In addition, the teacher also uses video media to support the implementation of learning so that all students are interested in the material delivered.

The evaluation system applied by the teacher is to provide the same material to all students including students with special needs, but the evaluation system is different, if a normal child is given questions and must be able to answer everything, for children with special needs can answer half of the questions given then he is considered can follow the learning that the teacher gives.

Table 1. The Results of Questionnaire Analysis

\begin{tabular}{llll}
\hline No & Result of Analysis & Score & Presentase \\
\hline 1 & Analysis of learning implementation plans & 99 & $99 \%$ \\
2 & Analysis of the implementation of learning & 102 & $85 \%$ \\
3 & Evaluation analysis of learning outcomes assessment & 54 & $75 \%$ \\
\hline
\end{tabular}

Tabel 2. Tabel Presentase Nilai

\begin{tabular}{ll}
\hline Answer & Information \\
\hline $0 \%-30 \%$ & None \\
$31 \%-60 \%$ & Less Complete \\
$61 \%-100 \%$ & Complete \\
\hline
\end{tabular}

Based on the results of the questionnaire analysis in the planning activities of learning the teacher was able to reach $99 \%$ of the results of the questionnaire that researchers did. That means the learning planning implementation component was in the "complete" category. In the process of implementing learning, teachers are able to reach $85 \%$ with the percentage value "in full compliance". The teacher is able to master the material and is able to implement the learning strategies that are made. In addition, teachers are also able to utilize learning resources / media in learning, although they are still lacking in involving students in utilizing these media. The results of the thematic learning assessment analysis in the class also showed the percentage reached $75 \%$ of the results of the questionnaire researchers conducted. This means that the assessment of learning falls into the "complete" category.

\section{Conclussion}

Based on the results Based on the results of data analysis and discussion the following conclusions can be drawn; (1) In terms of learning planning conducted by the teacher includes planning in the form of syllabus, lesson plans and approaches in learning planning; (2) In terms of the implementation of learning the teacher does not necessarily immediately start learning before the teacher approaches the student first, after the student feels comfortable the teacher starts implementing the learning by using models, methods and learning media; (3) In terms of the evaluation system conducted by the teacher, it includes cognitive, affective, and psychomotor aspects, evaluations conducted from normal children and children with special needs are not entirely the same.

\section{Reference}

Arikunto Suharsimi dan Cepi Safruddin Abdul Jabar. 2010. evaluasi progam pendidikan. Jakarta: Bumi Aksara.

Arikunto Suharsimi. 2010. “Prosedur Penelitian Suatu Pendekatan Praktik”. Yogyakarta: Rineka Cipta. 
Direktorat Pembinaan Sekolah Luar Biasa, (2007). Progam pendidikan khusus dan layanan pendidikan khusus. Jakarta :Depdiknas

Lexy, M.J.2010. Metodologi penelitian Kualitatif. Bandung: Remaja Rosdakarya

Majid Abdul. 2017. Pembelajaran Tematik Terpadu. Bandung: PT REMAJA ROSDAKARA.

Republik Indonesia.2003. Undang-Undang RI No. 20 Tahun 2003 SISDIKNAS. Jakarta

Republik Indonesia.2007. PERMENDIKNAS NO.41 TAHUN 2007. Standar Proses untuk Satuan Pendidikan Dasar dan Menengah. Jakarta 